\title{
Przerzuty raka pęcherza moczowego do prącia — opis trzech przypadków i przegląd piśmiennictwa
}

\author{
Bogumiła Szyszka-Charewicz, Jadwiga Nowak-Sadzikowska, \\ Tomasz Skóra, Mariusz Pietrasz, Jacek Ciupis, Jerzy Jakubowicz
}

\begin{abstract}
W tutejszym ośrodku leczono w ciągu 9 lat trzech pacjentów z rozsiewem nowotworowym z pęcherza moczowego do prącia. Rokowanie w przypadku przerzutów nowotworowych do prącia jest niekorzystne. Większość chorych umiera w ciągu roku od rozpoznania. Przeżycia leczonych przez nas pacjentów, wynoszące 6, 10 i 16 miesięcy od momentu rozpoznania przerzutu nowotworu do prącia, są porównywalne z opisywanymi w literaturze średnimi przeżyciami takich chorych.

U dwójki naszych pacjentów przerzuty do prącia były pierwszym objawem uogólnienia choroby nowotworowej, co wskazuje na konieczność brania pod uwagę możliwości wystąpienia przerzutów w tej lokalizacji w trakcie badań kontrolnych, zwłaszcza że u wszystkich opisanych przez nas pacjentów guzy przerzutowe były początkowo bezobjawowe. Wczesne rozpoznanie rozsiewu raka pęcherza moczowego do prącia umożliwia szybsze wdrożenie przyczynowego leczenia onkologicznego, które mogłoby poprawić jakość życia chorych. Po rozpoznaniu przerzutów do prącia lub równolegle do tego faktu doszło do uogólnionego rozsiewu choroby, co stanowiło o złym rokowaniu u naszych chorych mimo wdrożonego leczenia, co również opisano w literaturze.

Ze względu na rzadkie występowanie przerzutów do prącia nadal nie ustalono u takich chorych standardów postępowania przyczynowego i paliatywnego. W zależności od typu i zaawansowania guza pierwotnego oraz objawów i stanu ogólnego chorego stosuje się chirurgiczne usunięcie zmiany, całkowitą lub częściową resekcję prącia (ewentualnie z wyłonieniem ureterostomii), paliatywną radioterapię oraz chemioterapię. W przypadku nasilonego, trudnego do opanowania innymi metodami bólu, usuwa się nerw grzbietowy prącia.
\end{abstract}

\section{Metastatic cancer of the bladder to the penis - a report of three cases and a literature review}

Over the course of nine years three patients with penile metastasis seeding from a primary bladder cancer were treated at our centre. Penile metastatic disease is generally thought of as a poor prognostic indicator and most patients die within a year of their diagnosis. Survival of our patients following diagnosis ranged from six to sixteen months which is comparable to the average described in the literature. In two of our patients, penile metastasis was the first sign of cancer spread and importantly they were largely asymptomatic until this time. This should prompt clinicians to consider penile metastasis in their review of bladder patients. Patients should also be made aware of the various presenting symptoms. Early recognition of a penile metastasis would lead to the faster implementation of treatments thereby improving a patient's quality of life. As metastasis to the penis has a low incidence a causal understanding and defined palliative treatments remain uncertain in this group of patients. Depending on the type and severity of the primary tumour, symptoms secondary to the lesions and the patient's general condition, surgical 
removal of the lesion by total or partial resection of the penis, and possible ureterostomia, palliative radiotherapy and chemotherapy all remain treatment options to be considered. In cases of severe pain difficult to control by other means, the dorsal penile nerve may be removed.

Słowa kluczowe: przerzuty do prącia, rak pęcherza moczowego

Key words: metastases to penis, bladder cancer

\section{Wstęp}

Przerzuty nowotworowe do prącia są stosunkowo rzadkie, zwłaszcza jeśli bierze się pod uwagę częstość występowania nowotworów w sąsiedztwie oraz bogate unaczynienie narządu. Pojawiają się nawet teorie, że bardzo dobre ukrwienie prącia może paradoksalnie spełniać rolę chroniącą je przed przerzutami z innych narządów. Hipotezę tę wysunął Pond na podstawie podobieństwa ukrwienia ciał jamistych i śledziony. Ponieważ przerzuty nowotworowe do śledziony występują skrajnie rzadko, przez analogię do równie rzadkiego zjawiska występowania przerzutów do prącia stawia tezę, że to rodzaj ukrwienia pełni rolę ochronną, zarówno w prąciu jak i w śledzionie [1].

W 20\% przypadków przerzuty do prącia stwierdza się jednoczasowo z guzem pierwotnym, w 50\% przypadków następuje to w ciągu 2 lat od rozpoznania ogniska pierwotnego [2-4].

Najczęstsze są przerzuty z układu moczowo-płciowego, jelita grubego i odbytnicy. W sumie do tej pory opisano w piśmiennictwie około 470 przypadków chorych z przerzutami do prącia [5-7].

Pierwszy opis przerzutów nowotworowych do prącia ukazał się w 1870 roku [8] — ogniskiem pierwotnym był gruczolakorak odbytnicy, a pierwszy przypadek przerzutu z układu moczowego opisał Roberts w 1872 r. [9].

Większość autorów podaje jako najczęstsze ogniska pierwotne przerzutów do prącia: pęcherz moczowy (32\%), prostatę (30\%) oraz odbytnicę i esicę (13\%) [10-14]. Poza tym niewielki odsetek stanowiły przerzuty z nerek, jąder i okrężnicy. Ponadto autorzy opisali pojedyncze doniesienia dotyczące przerzutów z górnego odcinka przewodu pokarmowego, trzustki, nosogardła, języka, tarczycy, płuc, skóry i kości [5-7, 11-14].

Przerzuty do prącia zwykle są objawem niekorzystnym rokowniczo i towarzyszą rozsiewowi uogólnionemu [15], powodują zwykle istotne pogorszenie jakości życia chorych [16]. Najczęściej opisywane są jako bezbolesne guzy lub owrzodzenia, niekiedy jedynym objawem jest priapizm. U części chorych stwierdza się wyłącznie bóle w okolicy krocza i prącia, krwiomocz i trudności w oddawaniu moczu.

\section{Cel pracy}

Celem niniejszej pracy jest przedstawienie trzech przypadków chorych na raka pęcherza moczowego z przerzuta- mi do prącia, leczonych w Centrum Onkologii — Instytucie im. Marii Skłodowskiej-Curie, w Oddziale w Krakowie (COOK) w latach 2003-2012.

\section{Opisy przypadków}

Pierwszy z opisywanych pacjentów, 61-letni mężczyzna, zgłosił się do COOK 20 marca 2003 r. po przebytym dwukrotnie zabiegu przezcewkowej resekcji guza pęcherza moczowego z rozpoznaniem mikroskopowym carcinoma urotheliale G3, invasio muscularis.

W wykonanym badaniu MRI stwierdzono obecność nacieku ściany tylnej i lewej pęcherza moczowego, obejmującego moczowody. Chory nie wyraził zgody na zabieg operacyjny. Ze względu na stwierdzoną niewydolność nerek pacjent został zdyskwalifikowany z chemioterapii.W okresie 15 kwietnia 2003 r. do 29 maja 2003 r. przeprowadzono napromienianie wiązkami zewnętrznymi pęcherza moczowego z marginesem. Podano dawkę 60 Gy w 30 frakcjach, uzyskując całkowitą remisję procesu nowotworowego na ponad 3 lata.

Pacjent pozostawał bez objawów choroby do 11 lipca 2006 r., kiedy stwierdzono wznowę miejscową potwierdzoną mikroskopowo, i 18 października 2011 r. w COOK wykonano zabieg radykalnej cystektomii. Dwa miesiące później w trakcie badania kontrolnego stwierdzono u chorego obecność kilku zmian guzowatych w prąciu. Dnia 20 grudnia 2011 roku przeprowadzono częściową amputację prącia i wyłuszczenie jednocentymetrowego guza okolicy pachwinowej prawej, potwierdzając rozległy naciek raka urotelialnego ciała gąbczastego i obu ciał jamistych w połowie prącia, jak również węzłów pachwinowych prawych z przejściem nacieku na skórę. Do uzupełniającej chemioterapii chory nie został zakwalifikowany z powodu ciężkich schorzeń współistniejących. Po 6 miesiącach u chorego doszło do rozsiewu raka pęcherza do kości oraz moszny. W następnych miesiącach chory był paliatywnie napromieniany na zmiany przerzutowe w kościach i węzłach chłonnych oraz poddany paliatywnemu wyłuszczeniu guza moszny. Równocześnie u chorego prowadzono insulinoterapię cukrzycy, leczono przewlekłą niewydolność nerek i krążenia. Pacjent zmarł 21 kwietnia 2013 r., po 16 miesiącach od wystąpienia przerzutów do prącia.

Drugi z opisywanych pacjentów to 55-letni mężczyzna, u którego rozpoznano inwazyjnego, naciekającego 
mięśniówkę właściwą raka pęcherza moczowego w IVํoawansowania, z rozległym naciekiem obejmującym cały pęcherz oraz masywnymi przerzutami do węzłów chłonnych wzdłuż naczyń biodrowych i przestrzeni okołoaortalnej, sięgającymi do odnóg przepony. Pacjent został zakwalifikowany do paliatywnej chemioterapii, którą rozpoczął 29 października 2010 r.; otrzymał łącznie 6 serii chemioterapii wg schematu gemcytabina + cisplatyna. Ze względu na znaczną regresję nacieku ( $w$ badaniu TK widoczny resztkowy naciek $38 \times 25 \mathrm{~mm}$ ) oraz znaczne zmniejszenie pakietów węzłów chłonnych chorego zakwalifikowano do paliatywnej radioterapii. W dniach od 11 kwietnia 2011 r. do 20 maja 2011 r. podano dawkę 45 Gy w 25 frakcjach na pęcherz z marginesem, z uzupełnieniem dawki o 13,5 Gy w 9 frakcjach na zmniejszony obszar techniką concomitant boost, ze średnią tolerancją leczenia (ból o nasileniu G3, odczyn ze strony jelit G1, ze strony pęcherza G2 wg skali RTOG/EORTC). Trzy miesiące później w badaniu kontrolnym stwierdzono obecność stwardnienia u podstawy prącia, obejmującego cały obwód, ciągnącego się na długości $5 \mathrm{~cm}$. W USG opisano pogrubienie i poszerzenie obu ciał jamistych prącia do $36 \times 28 \mathrm{~mm}$ na długości $6 \mathrm{~cm}$ - ich struktura była niejednorodna, odcinkowo zacierała się granica między ciałami jamistymi, co budziło podejrzenie zmian przerzutowych. 18 listopada 2011 r. pobrano głęboki, klinowy wycinek z ciał jamistych, uzyskując rozpoznanie mikroskopowe nacieku raka urotelialnego ciał jamistych. Chory pozostawał leczony objawowo. W badaniu TK wykonanym miesiąc później ujawnił się rozsiew do płuc i węzłów chłonnych przytchawiczych dolnych lewych, przedostrogowych, podostrogowych i przytchawiczych górnych prawych, bez cech wznowy w pęcherzu. Chory rozpoczął 16 lutego 2012 r. chemioterapię drugiego rzutu według schematu metotreksat, cisplatyna, doksorubicyna i winblastyna, otrzymał III serie chemioterapii. Ponieważ w trakcie chemioterapii doszło do wytworzenia przetoki na grzbiecie prącia, dnia 17.04 wytworzono przetokę punkcyjną pęcherza moczowego. W kontrolnym badaniu KT uwidoczniono progresję w zakresie zmian przerzutowych w płucach i obustronnie w węzłach chłonnych pachwinowych. Z powodu progresji procesu nowotworowego chorego zakwalifikowano do chemioterapii III rzutu w oparciu o paklitaksel w monoterapii: otrzymał pierwszą serię leczenia 15 maja 2012 r., ale w terminie drugiej serii stwierdzono u pacjenta gwałtowną progresję miejscową w postaci 6-centymetrowego pakietu węzłów w lewej pachwinie. Całe prącie objęte było rozpadającym się naciekiem z owrzodzeniem i martwicą. Zdecydowano o zakończeniu leczenia przyczynowego. Chorego skierowano do dalszego leczenia objawowego w hospicjum domowym. Niespełna 2 miesiące później pacjent zmarł, w sumie 12 miesięcy od momentu wystąpienia przerzutów do prącia.

Trzeci z opisywanych chorych to mężczyzna 77-letni, który zgłosił się do COOK 9 lipca 2012 r., skierowany przez poradnię urologiczną szpitala w Proszowicach po cystektoprostatectomii z powodu raka urotelialnego G2 oraz amputacji prącia z powodu przerzutu raka urotelialnego. W wykonanym badaniu stwierdzono masywne zajęcie węzłów chłonnych biodrowych zewnętrznych, wspólnych prawych i pachwinowych. Wobec rozsiewu raka pęcherza moczowego chory zakwalifikowany został do paliatywnej chemioterapii. W dniach od 14-16 stycznia 2013 r. otrzymał I serię wg schematu karboplatyna + gemzar, w dawkach zredukowanych o $20 \%$ ze względu na cechy niewydolności nerek. Kolejnej serii chemioterapii nie podano ze względu na pogorszenie się stanu ogólnego i progresję procesu nowotworowego. Chorego skierowano do opieki hospicyjnej około 14 lutego 2013 r., gdzie zmarł 2 miesiące później, w sumie 10 miesięcy od momentu wystąpienia przerzutów do prącia.

\section{Dyskusja}

Rokowanie w przypadku przerzutów nowotworowych do prącia jest niekorzystne. Większość chorych umiera w ciągu roku od ich rozpoznania, opisywane są zaledwie pojedyncze przypadki przeżyć długotrwałych. Najdłuższe z nich wynosiły: 7 lat w przypadku ogniska pierwotnego w prostacie i 9 lat w przypadku przerzutów raka zlokalizowanego w odbytnicy [11]. Średnie przeżycie chorych z przerzutami do prącia ocenia się na 6,0 do 12,0 miesięcy od chwili ich rozpoznania $[4,17,18]$. U opisywanych przez nas pacjentów okres ten wynosił kolejno 16 miesięcy, 12 miesięcy i 10 miesięcy.

Najczęstszą lokalizacją przerzutów jest trzon prącia, w odróżnieniu od pierwotnych nowotworów tego narządu, które typowo lokalizują się w żołędzi i napletku. U wszystkich trzech opisywanych chorych lokalizacja przerzutów była typowa.

Najczęściej przerzuty znajdowane są w ciałach jamistych [4, 17-20]. Nie opisywano przypadku zajęcia wyłącznie ciała gąbczastego, co zdaniem niektórych autorów dowodzi, że zabiegi wykonywane przez cewkę moczową nie przyczyniają się do rozsiewu nowotworowego do prącia [17].

Prącie jest narządem dobrze unaczynionym, połączonym siecią naczyń krwionośnych oraz limfatycznych $z$ innymi strukturami miednicy. Nie jest dokładnie poznany sposób powstawania przerzutów do tego narządu. Opisuje się 6 prawdopodobnych mechanizmów:

\section{Wsteczna droga żylna}

Przyjmuje się, że jest to najczęstszy mechanizm $[2,17]$. Łatwość przenoszenia komórek nowotworowych zapewniają istniejące połączenia między żyłą grzbietową penisa a splotami żylnymi drenującymi narządy miednicy — ta droga rozsiewu tłumaczy, dlaczego większość przerzutowych nowotworów wywodzi się z narządów znajdujących się powyżej prącia, czyli gruczołu krokowego, pęcherza mo- 
czowego i odcinka esiczo-odbytniczego jelita grubego. Ta droga tłumaczy również najczęstsze umiejscowienie guzów przerzutowych w ciałach jamistych prącia, gdyż odwrócony przepływ w tych kanałach umożliwia krwi żylnej z miednicy bezpośredni dostęp do prącia. Czasami może przejściowo dochodzić do odwróconego przepływu spowodowanego wzrostem ciśnienia śródbrzusznego przy uruchomieniu tłoczni brzusznej w trakcie kaszlu lub kichania [2].

\section{Wsteczna droga chłonna}

Ten mechanizm jest podobny do poprzedniego [17]. Naczynia chłonne prącia, podobnie jak dna pęcherza moczowego i tylnej powierzchni gruczołu krokowego, drenują do węzłów chłonnych biodrowych zewnętrznych. Podobnie naczynia z dolnej części odbytnicy przechodzą przez obszar krocza do węzłów chłonnych pachwinowych, a następnie biodrowych. Połączenia te stanowią znakomity szlak dla rozsiewu naczyniami chłonnymi, albo poprzez przenikanie, albo w wyniku tworzenia zatorów. Ta droga odpowiada raczej za przerzuty do skóry prącia niż do ciał jamistych lub żołędzi.

\section{Droga tętnicza}

Ten sposób rozsiewu nie jest częsty i być może to tłumaczy rzadkość przerzutów mięsaków do prącia [2]. Są trzy możliwe drogi dostępu komórek nowotworowych do krążenia tętniczego: bezpośrednie szerzenie się guza w układzie tętniczym, np. gałęziami tętnicy podbrzusznej, wtórnymi zatorami komórek nowotworowych, np. z przerzutów do płuc, oraz trzeciorzędowymi zatorami, gdy przerzuty do wątroby są źródłem przerzutów do płuc, a te z kolei dają przerzuty do penisa [17].

\section{Bezpośrednie szerzenie się}

Ten sposób szerzenia się jest możliwy z narządów sąsiadujących, czyli guzów gruczołu krokowego i pęcherza moczowego. Poza tym komórki z nowotworów dolnej części odbytnicy mogą rozprzestrzeniać się wzdłuż dołów kulszowych na nasadę prącia. Ta droga może odpowiadać za zmiany na bliższej części trzonu prącia, które, co ciekawe, znacznie rzadziej występują niż te w ciałach jamistych i żołędzi.

\section{Wszczepienie i przerzuty po ingerencji zabiegowej}

Zostały opisane jako możliwe sposoby rozsiewu do prącia, mimo że wydają się mało prawdopodobne, jako że izolowane przerzuty do ciała gąbczastego bez równoczesnego zajęcia ciał jamistych praktycznie nie występują [17].

\section{Przedostawanie się komórek nowotworowych przez przetrwały otwór owalny do serca [11, 14]}

W różnicowaniu zmian przerzutowych należy uwzględnić pierwotne nowotwory złośliwe prącia, kiłę, wrzód miękki, gruź- licę oraz inne choroby zakaźne tego narządu, zakrzepicę żył lub/i ciałjamistych, chorobę Peyronie'a oraz bolesny wzwód prącia.

Ze względu na rzadkie występowanie przerzutów do prącia nadal nie ustalono u takich chorych standardów postępowania przyczynowego i paliatywnego.W zależności od typu i zaawansowania guza pierwotnego oraz objawów i stanu ogólnego chorego stosuje się chirurgiczne usunięcie zmiany, całkowitą lub częściową resekcję prącia (ewentualnie z wyłonieniem ureterostomii), paliatywną radioterapię oraz chemioterapię. W przypadku nasilonego, trudnego do opanowania innymi metodami bólu, usuwa się nerw grzbietowy prącia [3].

\section{Konflikt interesów: nie zgłoszono}

\section{Dr Mariusz Pietrasz}

Centrum Onkologii - Instytut

im. Marii Skłodowskiej-Curie

Oddział w Krakowie

ul. Garncarska 11,31-115 Kraków

e-mail:mmpietrasz@gmail.com

Otrzymano: 22 lutego 2015 r.

Przyjęto do druku: 19 marca 2015 r.

\section{Piśmiennictwo}

1. Pond HS, Wade JC. Urinary obstruction secondary to metastatic carcinoma of the penis: a case report and review of the literature. $J$ Urol 1969; 102: 333-335.

2. Abeshouse BS, Abeshouse GA. Metastatic tumors of the penis: a review of the literature and a report of two cases. J Urol 1961; 86: 99-112.

3. Hayes WT, Young JM. Metastatic carcinoma of the penis. J Chronic Dis 1967; 20: 891-895.

4. Mukamel E, Farrer J, Smith RB i wsp. Metastatic carcinoma of the penis. When is total penectomy indicated? Urology 1987; $24: 15$

5. Perez LM, Shumway RA, Carson CC i wsp. Penile metastasis secondary to supraglottic squamous cell carcinoma: Review of the literature. JUrol 1992; 147: 157.

6. Hizli F, Berkmen F. Penile metastasis from other malignancies. A study of ten cases and review of the literature. Urol Int 2006; 76: 118-121.

7. Chaux A, Amin M, Cubilla AL i wsp. Metastatic tumors to the penis: A report of 17 cases and review of the literature. Int I Surg Pathology 2011; 19: 597-606.

8. Eberth CJ. Krehsmetastasen des corpus cavernosum penis. Virch Arch 1870; 51: 145.

9. Roberts W. A practical treatise on urinary and renal disease. $2^{\text {nd }}$ edition. London: Smith, Elder and Co; 1872: 517.

10. Andersen R, Wegner HEH, Dieberg S. Penile metastasis of sigmoid carcinoma: comparative analysis of different imaging modalities. $\mathrm{Br}$ JUrol 1997; 79: 477-478

11. Guimaraes G, De Souza R, Guimaraes A i wsp. Penile metastatis of chondrosarcoma of the jaw. Urology 2003; 61: 837-840.

12. Grimm M, Spiegelhalder P, Heep H i wsp. Penile metastasis secondary to follicular thyroid carcinoma. Scand J Urol Nephrol 2004; 38: 253-255.

13. Berger $\mathrm{A}$, Rogatsch $\mathrm{H}$, Hoeltl $\mathrm{L}$ i wsp. Late penile metastasis from primary bladder carcinoma. Urology 2003; 62: 145.

14. Ansari H, Prashant R, Franks A. Prostatic carcinoma metastasis to the penis- an uncommon site. Lancet Oncol 2003; 4: 705-706.

15. Cherian J, Rajan S, Thwaini A i wsp. Secondary penile tumours revisited. International Sem Surg Oncol 2006; 3: 33.

16. Czufryn A, Serkies K, Kowalczyk A i wsp. Penile metastases from rectal carcinoma: case report and review of the literature. Onkol Prakt Klin 2006; 2: 145-147.

17. Paquin AJ Jr, Roland SJ. Secondary carcinoma of the penis: a review of the literature and report of nine new cases. Cancer 1956; 9:626.

18. Robey EL, Schellhammer PF. Four cases of metastases to the penis and review of the literature. J Urol 1984; 132; 992.

19. MalczykE, Werel I, Kudelski J. Priapizm jako jeden z pierwszych objawów w zaawansowanym raku pecherza moczowego. Urol Pol 1992; 45; 218

20. McCrea LE, Tobias GL. Metastatic disease of the penis. J Urol 1958; 80; 489. 